Cita: Mahedero, P.; Calderón, A.; Martínez de Ojeda, D.; Arias-Estero, J. L. (2022). Impact of two sport education units on learning outcomes in primary school. Cuadernos de Psicología del Deporte, 22(1), 160-175

\title{
Impacto de Dos Unidades Didácticas de Educación Deportiva sobre Objetivos de Aprendizaje en Educación Primaria
}

\section{Impact of Two Sport Education Units on Learning Outcomes in Primary School}

\section{Impacto de Duas Unidades Didáticas de Educação Esportiva nos Objetivos de Aprendizagem do Ensino Fundamental}

\author{
Mahedero, P. ${ }^{1}$, Calderón, A. ${ }^{2}$, Martínez de Ojeda, D. ${ }^{3}$, Arias-Estero, J. L. ${ }^{4}$ \\ ${ }^{1}$ Consejería de Educación y Deporte de la Junta de Andalucia; ${ }^{2}$ University of Limerick, Limerick, \\ Ireland; ${ }^{3}$ Consejería de Educación y Cultura de la Región de Murcia, ${ }^{4}$ Universidad de Murcia, Murcia, \\ España
}

\begin{abstract}
RESUMEN
Los objetivos del estudio fueron: (a) explorar el efecto de dos unidades didácticas de educación deportiva (baloncesto y floorball) sobre el rendimiento de juego y el conocimiento de alumnado de educación primaria, de acuerdo con su nivel de habilidad, y (b) conocer si hubo diferencias de acuerdo con el deporte (baloncesto y floorball). Los participantes fueron 33 alumnos de dos clases de educación primaria. Este estudio siguió un enfoque de métodos mixtos. Los datos cuantitativos se obtuvieron mediante un diseño cuasi-experimental pretest-postest. Los datos cualitativos se obtuvieron después de la intervención. Se aplicaron dos unidades didácticas (baloncesto y floorball) en dos clases diferentes, una clase experimentó la unidad de baloncesto y la otra la de floorball y viceversa. Se analizaron variables relacionadas con el rendimiento de juego (toma de decisión, ejecución técnica, rendimiento de juego, implicación en el juego) y el conocimiento. Los resultados de aprendizaje del alumnado fueron también analizados utilizando datos cualitativos del: (a) análisis realizado por expertos y (b) la percepción de los propios alumnos y el maestro. Los resultados fueron afectados por el deporte enseñado y el nivel de habilidad del alumnado. El maestro enfatizó que fue complejo para el alumnado de primaria comprender determinados conceptos tácticos y técnicos, especialmente en floorball. En educación primaria, la experiencia previa del alumnado con el contenido y el nivel de habilidad condicionó los resultados de las variables relacionadas con el rendimiento de juego y el conocimiento. Se sugiere que las unidades didácticas basadas en el modelo de educación deportiva en deportes de invasión con implemento, como ocurre en floorball en educación primaria, podría requerir de una instrucción más concreta y unidades didácticas más largas con el fin de garantizar un nivel mínimo de aprendizaje técnico y táctico.
\end{abstract}

Palabras clave: pedagogía deportiva; deportes de equipo; modelos pedagógicos; contextos de enseñanzaaprendizaje.

\section{ABSTRACT}




\section{Unidades Didácticas de Educación Deportiva para la Educación Primaria}

The purposes of the study were (a) to explore the effect of two-Sport Education units (basketball and floorball) on game performance and game knowledge of Primary Education students according to their skill level, and (b) to know whether there were differences according to the sport taught (basketball and floorball). The participants were 33 students from two primary school classes. This study followed a mixed-methods approach. Quantitative data were obtained through a cuasi-experimental pretest-posttest design. Qualitative data were obtained after the intervention. Two teaching units (basketball and floorball) were applied in two different classes, one class experienced the basketball unit and the other the floorball unit and vice versa. We analysed game performance variables (decision making, skill execution, game performance, game involvement) and game knowledge. Students' performance was also measured using qualitative data which were collected through two methods: (a) experts' analysis on game performance of students, and (b) students' and teacher's perception of students' performance with Sport Education. The results were affected both the sport taught and the skill level of students. The teacher emphasized that it was very complex for the primary students to understand some tactical and technical concepts, especially in floorball. At the primary level, student previous experience with the content and skill level conditioned the results in the variables related with game performance and knowledge. It is suggested that enacting Sport Education units of invasion games with implement such as floorball, at the primary level, might require more explicit instruction and longer teaching units in order to guarantee a minimum level of technical and tactical improvement.

Keywords: sport pedagogy; team sports; pedagogical models; teaching-learning contexts.

\section{RESUMO}

Os objetivos do estudo foram: (a) explorar o efeito de duas unidades didáticas de educação esportiva (basquete e floorball) no desempenho de jogo e no conhecimento de alunos do ensino fundamental, de acordo com seu nível de habilidade, e (b) saber se houve diferenças de acordo com o esporte (basquete e floorball). Os participantes foram 33 alunos de duas turmas do ensino fundamental. Este estudo seguiu uma abordagem de métodos mistos. Os dados quantitativos foram obtidos por meio de um desenho pré-teste-pós-teste quase experimental. Os dados qualitativos foram obtidos após a intervenção. Duas unidades didáticas (basquete e floorball) foram aplicadas em duas turmas distintas, uma aula experimentou a unidade de basquete e a outra a unidade de floorball e vice-versa. Variáveis relacionadas ao desempenho do jogo (tomada de decisão, execução técnica, desempenho do jogo, envolvimento no jogo) e conhecimento foram analisadas. Os resultados de aprendizagem dos alunos também foram analisados com base em dados qualitativos de: (a) análise realizada por especialistas e (b) a percepção dos próprios alunos e do professor. Os resultados foram afetados pelo esporte ensinado e pelo nível de habilidade dos alunos. O professor enfatizou que foi difícil para os alunos do ensino fundamental entender alguns conceitos táticos e técnicos, principalmente no floorball. No ensino fundamental, a experiência prévia dos alunos com o conteúdo e o nível de habilidade condicionou os resultados das variáveis relacionadas ao desempenho e conhecimento do jogo. Sugere-se que a utilização de unidades didáticas baseadas no modelo de educação esportiva em esportes de invasão com implemento, como ocorre no floorball no ensino fundamental, poderia exigir instrução mais específica e unidades didáticas mais longas para garantir um nível mínimo de aprendizagem técnico e tático.

Palavras chave: pedagogia do esporte; esportes coletivos; modelos pedagógicos; contextos de ensino-aprendizagem.

\section{INTRODUCTION}

The three learning outcomes of Sport Education are to produce competent, literate and enthusiastic sports players (Siedentop, 2002). According to Hastie and Wallhead (2016) these primary goals for Sport Education initially delineated by Siedentop are both realistic and achievable. Nevertheless, despite Sport
Education is the "pedagogical model that is arguably the best developed to date, the most often researched" (Kirk, 2013, p. 979), "there remains future roads to be travelled if the case is to be firmly made that Sport Education is capable of delivering on its potential" as Hastie and Wallhead (2016, p. 397) recommended. From the research design perspective, findings from 


\section{Mahedero et al.}

qualitative approaches using both interpretive and critical lenses of interpretation as well as the actionbased research designs can be a guide for futures pedagogical iterations of the model applied within more generalizable positivist, experimental designs (Farias et al., 2018; Hastie \& Wallhead, 2016).

Research from the early 1980 s to the present mainly has been focused on: (a) the effect of this model on the enthusiastic participation of primary and secondary students (e.g., Browne et al., 2004; Hastie, 1998; Pope \& Grant, 1996); on the effect on skill level improvements estimated from the students' and teacher' perceptions (e.g., Gutiérrez et al., 2014; Siedentop, 2002); (b) on the effect of comparing Sport Education with other curriculum models (e.g., Iserbyt et al., 2016; Pereira et al., 2015), especially with direct instruction (e.g., Layne \& Yli-Piipari, 2015; Perlman, 2010; Pritchard et al., 2008); (c) on the effect of blending some features with alternative models to better achieve specific learning goals (e.g., Araújo et al., 2016); and recently, (d) on the student-coaches' pedagogical behaviour (e.g., Araújo et al., 2017; Farias et al., 2018) and (e) on the experiences from Physical Education teacher education (e.g., Hordvik et al., 2017, 2019). That stated, there is still a lack of empirical evidences and quantitative measures to validate the improvement on the competence (game performance) and the literate features (game knowledge) of students, especially at primary level and focus on invasion games that use implements.

It is also worth noting that, for Lee et al. (1993) and Silverman et al. (1998) students learned motor skills in Physical Education when they practiced in an appropriate difficulty level. Accordingly, it is important to consider the student ability level to establish groups and to evaluate the teaching and learning process, as it could influence their learning experiences in Physical Education (Silverman, 1993). Up to date only few the researches have considered the ability level of primary or secondary students to analyse the game performance and game knowledge improvements after one or more units (Farias et al., 2019; Hastie, 1998; Hastie et al., 2017; Mahedero et al., 2015; Mahedero et al., 2021; Mesquita et al., 2012; Pereira et al., 2015). Although certainly, grouping students by skill level has also been studied from other points of view, such as the effect of peer interaction on social skills and the inclusion of students with special needs or those with lower initial skill levels (Lafont et al., 2017), the frequency and focus of students' verbal exchanges during a season of Sport Education (Brock \& Hastie, 2017) or the power relations in Physical Education group work (Barker \& Quennerstedt, 2017). In fact, despite of the importance of the skill level as a variable that influence achievement, most of the research on Sport Education has not contemplated it as a mediating variable.

The study of Mahedero et al. (2015) showed that the students who participated in heterogeneous skill level groups with Sport Education improved their game knowledge highlighting that the lower level students learned more quickly thanks to greater participation, concentration and responsibility for their individual learning. Hastie et al. (2017) highlighted that lower skilled students were at a disadvantage in terms of their engagement rates and playing efficiencies when they participated alongside higher skilled classmates. Farias et al.'s (2019) key finding was that performance improvements were associated with contextual features of extended team membership and consequent attunement of game-play interpersonal dynamics, nature of peer-teaching mediation, and game forms design. Finally, Mahedero et al. (2021) found that grouping students by skill level had no impact on gains in game performance and knowledge despite the fact that Sport Education literature shows a preference for heterogeneity in ability-based grouping.

What is demonstrated is that most of the studies have analyzed the impact of Sport Education in nonimplement invasion games as rugby, or ultimate at the primary level but especially at secondary level. For example, Browne et al. (2004) who compared Sport Education and direct instruction in a rugby unit, showing that the secondary students perceived improvements on their game performance and game knowledge level. At the primary level, the study of Hastie (1998) reported improvement in skill execution and decision making, whereas Mesquita et al. (2012) reported a higher improvement for girls and low skilllevel students. Yet, the findings of Hastie and Sinelnikov (2006) showed that the students were highly engaged within the skill practice and gameplaying tasks during a basketball unit, taking their officiating roles seriously and diligently and showing powerful enthusiasm towards their teams. 


\section{Unidades Didácticas de Educación Deportiva para la Educación Primaria}

As noted earlier, the review of Araújo et al. (2014) on the level of competence of the student concluded that the analysis of student learning has been focused on a superficial evaluation of the teaching-learning process, especially in Primary Education. In fact, Sport Education research on student learning has mainly focused on assessing student improvement using quasi-experimental (pre-test, post-test), descriptive and exploratory perceptions of students and teacher to obtain performance measures. Accordingly, the literature proposes to verify following an experimental or quantitative analysis the effect of Sport Education on different variables such us the type of sport or the student skill level (Araújo et al., 2016). Particularly at the primary level, in which there is a lack of research on Sport Education and game performance related variables.

Given this scenario, the purposes of the paper were: (a) to explore the effect of two- Sport Education invasion games units (basketball and floorball) on game performance and game knowledge of Primary Education students according to their skill level, and (b) to know whether there were differences according to the sport taught (basketball and floorball). Based on prior results, it was hypothesized that after this experience with Sport Education, the level of game performance and game knowledge of primary students will improve regardless their skill level and the sport taught.

\section{MATERIAL AND METHOD}

\section{Participants}

Thirty-three students from two coeducational primary school classes $(15$ boys and 18 girls, average age $=$ 10.4 years old) completed 14 lessons in two teaching units (basketball and floorball). Students had experience in basketball (one teaching unit taught the previous term) but not floorball. In order to produce more valid results and promote experimental control, only those students who attended at least eleven of the fourteen sessions of each teaching unit and who completed all assessment instruments were included in the analysis. In addition, one Physical Education male teacher participated. Participants were selected on purpose because students and teacher had no prior experience with Sport Education. In addition, because of the study had the approval of the board of the school and parents or legal guardians of each student signed the informed consent letter to allow their child to participate in the study. The school, that was located in south-eastern Spain, was coeducational, public, urban, and non-religious. The students were of middle socio-economic status. The study had the approval of the Ethics Committee of the first researcher's university and participants provided their assent (7/3/2014).

\section{Design}

This study followed a mixed-methods approach. Quantitative data were obtained through a cuasiexperimental pretest-posttest design. Qualitative data were obtained after the intervention. Two teaching units (basketball and floorball) were applied in two different classes, one class experienced the basketball unit and the other the floorball unit and vice versa.

Both classes practiced under the main premises of Sport Education (Siedentop et al., 2019, same teams throughout the unit, a team-practice area, the same colours of shirts, and they also assumed individual roles). Students in each class were divided into heterogeneous level groupings based upon a preliminary test on game performance before the pretest of each teaching unit, calculated using the game performance assessment instrument (GPAI, Oslin et al., 1998). This test was made one week before the application of both units. Groupings (three to four students per teams) were established randomly depend on their skill level scored in the preliminary test and remained constant throughout the two Sport Education units.

Pretest on game performance variables (decision making (DM), skill execution (SE), game performance (GP), game involvement (GI)) and game knowledge (GK) took place before the application of each unit (basketball and floorball), and posttest took place after the end of each unit. At the end of both units the students' performance was also measured using qualitative data which were collected through two methods: (a) experts' analysis on game performance of students, and (b) students' and teacher' perception of students' performance with Sport Education.

\section{Procedure}

Unit design and lesson content. The basketball and floorball units were taught twice a week over a period of seven weeks. Pretest and posttest were performed 


\section{Mahedero et al.}

before and after each unit. Each lesson was scheduled for 60 minutes. In assessing the level of instructional and treatment validity, the guidelines of Hastie and Casey (2014) on fidelity models-based practice research, and the Araújo et al. (2014) study quality scores were followed. That was: (a) a detailed description of the program context; (b) details of outcome assessment; (c) instrument reliability; (d) details of the interventions; (e) fidelity of the intervention; and (f) report the effect size. Lesson content plan and the tasks performed in each of the units are shown in Figure 1.

Teacher expertise. The teacher had been teaching Physical Education in Primary Schools for ten years, and he had previous experience with one 15 lessons Sport Education rugby-tag season (a year before). In addition, he received formal instruction and training in Sport Education following the directions of Dyson et al. (2004). A comprehensive experience was conducted which included: (a) training by different Sport Education experts on the basic principles of Sport Education (10 hours); (b) training in the development of a specific module of Sport Education (10 hours theory +10 hours practice); (c) observations of the actual implementation of a teaching unit (handball) with Sport Education in high school students; and (d) experience in implementing a Sport Education unit with classes other than those used in this study. From a theoretical point of view, the training consisted of four contents: (a) pedagogical features of Sport Education, (b) teacher and students' expected behaviours during the intervention, (c) keys in the designing of lessons, and (d) designing of a Sport Education unit. From a practical point of view, the training integrated: (a) participation in five Sport Education lessons as a student, (b) observation and checking the teacher and student' behaviours during the Sport Education lessons, and (c) discussion with the teacher of the Sport Education lessons experienced about the crucial aspect of the model.

Verification of treatments. Randomly selected lessons (second, fifth, sixth and eleventh) were sent to an external reviewer expert in order to verify using the Sinelnikov (2009) checklists, that both teaching units were being implemented suitably. After this assessment the expert provided a feedback to the teacher to enrich the following lessons. An average from in between 16 and 19 criteria from a total of 23 were addressed in the four lessons evaluated. In addition, the same external reviewer made, as Sinelnikov (2009) suggested, regular lesson observation as well as briefing and debriefing all the sessions to provide the feedback necessary for the teacher to provide validation of the congruency of his teaching to Sport Education.

\section{Data collection}

Game performance. Digital video records were made of students' game performance variables at both pretest and posttest in each teaching unit. Each student was recorded for eight minutes during these observations (pretest and posttest). Game performance variables were assessed using the GPAI. For this study the most used and fundamental indexes of GPAI were assessed: (a) $\mathrm{DM}=$ appropriate decisions making / inappropriate decisions making; (b) SE = appropriate technical execution / inappropriate technical execution; (c) GP = $(\mathrm{DM}+\mathrm{SE}) / 2)$; and (d) GI $=$ appropriate decisions making + inappropriate decisions making + appropriate technical execution + inappropriate technical execution.

An appropriate DM in basketball is defined as those actions in which the player tries to (a) pass the ball to a teammate without adversaries or being received it by the teammate of the same team; (b) threw the ball without losing possession of it, with or without defences nearby; (c) shooting a basket by having the ball at least touch the hoop, with or without opponents. An appropriate DM in floorball is defined as those actions in which the player tries to: (a) passing the ball to the teammate without opposing or being received by a member of your team; (b) to conduct the ball without losing its possession, with or without defences nearby, within the limits; (c) throwing a goal without defences and / or without intercepting the ball by an opponent within the limits or space delimited by the goal.

\begin{tabular}{|c|c|c|c|c|}
\hline Lesson & Teacher's role & Student's role & Basketball & Floorball \\
\hline
\end{tabular}




\section{Unidades Didácticas de Educación Deportiva para la Educación Primaria}

\begin{tabular}{|c|c|c|c|c|}
\hline 1 & Class leader & Participant & $\begin{array}{l}\text { Introduction to Sport } \\
\text { Education and sport. } \\
\text { Role assignment. } \\
\text { Assigned team. }\end{array}$ & $\begin{array}{l}\text { Introduction to Sport } \\
\text { Education and sport. } \\
\text { Role assignment. } \\
\text { Assigned team }\end{array}$ \\
\hline $\begin{array}{l}2 \\
3 \\
4\end{array}$ & Class leader & Participant & $\begin{array}{l}\text { General technical }{ }^{2} \text { and } \\
\text { tactical }^{3} \text { skills. } \\
\text { Basic rules. } \\
\text { Description of daily } \\
\text { roles. }\end{array}$ & $\begin{array}{l}\text { General technical }^{4} \text { and } \\
\text { tactical }^{5} \text { skills. } \\
\text { Basic rules. } \\
\text { Description of daily } \\
\text { roles. }\end{array}$ \\
\hline $\begin{array}{l}5 \\
6\end{array}$ & $\begin{array}{l}\text { Head coach, } \\
\text { Referee advisor }\end{array}$ & $\begin{array}{l}\text { Coaches, players, learn duty } \\
\text { role, practise duty roles }{ }^{1}\end{array}$ & $\begin{array}{l}\text { General technical and } \\
\text { tactical skills. } \\
2 \text { vs } 2\end{array}$ & $\begin{array}{l}\text { General technical and } \\
\text { tactical skills. } \\
2 \text { vs } 2\end{array}$ \\
\hline $\begin{array}{l}7 \\
8\end{array}$ & $\begin{array}{l}\text { Head coach, Referee } \\
\text { advisor }\end{array}$ & $\begin{array}{l}\text { Coaches, players, learn duty } \\
\text { role, practise duty roles }\end{array}$ & $\begin{array}{l}\text { General technical and } \\
\text { tactical skills. } \\
3 \text { vs } 3\end{array}$ & $\begin{array}{l}\text { General technical and } \\
\text { tactical skills. } \\
3 \text { vs } 3\end{array}$ \\
\hline $\begin{array}{c}9 \\
10\end{array}$ & $\begin{array}{l}\text { Head coach, } \\
\text { Referee advisor }\end{array}$ & $\begin{array}{l}\text { Coaches, players, learn duty } \\
\text { role, practise duty roles }\end{array}$ & $\begin{array}{l}\text { General technical and } \\
\text { tactical skills. } \\
4 \text { vs } 4\end{array}$ & $\begin{array}{l}\text { General technical and } \\
\text { tactical skills. } \\
4 \text { vs } 4\end{array}$ \\
\hline $\begin{array}{l}11 \\
12 \\
13\end{array}$ & Programme manager & Duty team roles ${ }^{4}$ & $\begin{array}{l}\text { Tournament } \\
4 \text { vs } 4\end{array}$ & $\begin{array}{l}\text { Tournament } \\
4 \text { vs } 4\end{array}$ \\
\hline 14 & Master of ceremonies & Participant & $\begin{array}{l}\text { Final Competition } \\
\text { Festivity } \\
\text { Award ceremony }\end{array}$ & $\begin{array}{l}\text { Final Competition } \\
\text { Festivity } \\
\text { Award ceremony }\end{array}$ \\
\hline
\end{tabular}

Figure 1. Features of basketball and floorball units. Note: ${ }^{1}$ duty roles (referee + score keeper); ${ }^{2}$ pass, threw and shooting the ball; ${ }^{3}$ defensive play: rebound, triple threat and position, and attacking play: counterattack; ${ }^{4}$ pass, threw and throwing the ball; ${ }^{5}$ defensive play: retrieve and protect the goal, and attacking play: counterattack.

In SE was considered appropriate in basketball in the following cases: (a) the player accompanied the pass by advancing one of his feet, with one or two hands and / or leg extension; (b) the player threw the ball over the knee and under the shoulder, with one hand; (c) the player accompanied the shooting basket by advancing one of his feet and / or accompanying with the body, as well as in running. An SE was considered appropriate in floorball in the following cases: (a) the player accompanied the pass of the ball with the movement of the stick; (b) the player kept the stick with both hands to drive the ball and control the movement of the ball; (c) the player threw a goal with both hands on the stick, directing the ball towards the goal (within limits) and / or body movement.

To ensure the reliability of the GPAI data, three observers were trained more than 10 hours throughout six meetings classroom viewing and analyzing video clips of basketball and floorball (different video clips than used during data collection). The observers were considered adequately reliable when they were able to achieve a $90 \%$ (intraclass correlation coefficient> 0.90 ) accurate standard with respect to both obtain intra- and interobserver reliability. This was calculated by means of the intraclass correlation coefficient and percent agreement ((agreement/disagreement)*100) achieved following a 12 minutes assessment of two single players (a basketball player and a floorball player) at two intervals separated by two weeks.

Reliability of the pre and posttest data was measured through interobserver evaluation among the three coders. In these evaluations, the observers analyzed more than $15 \%$ of studio participant players (six students, three basketball players and three floorball players). Reliability of the observation reached intraclass correlation values between .94 and .91, and percent agreement values between $87.09 \%$ and $90.32 \%$.

Game knowledge. GK was measured through the use of two, true and false ad hoc and validated tests (one for basketball and other for floorball). They were 


\section{Mahedero et al.}

designed from the contents addressed in the lessons and in collaboration with the teacher following the proposal of French and Thomas (1987). The tests were administered both before each unit began and again on completion of them with an average time for completion being 15 minutes each one. The tests consisted of four questions concerning technique, three concerning tactics and five concerning rules about the sports of basketball and floorball, respectively.

Experts' analysis of game performance. To provide a more qualitative understanding, five experts in team sports were required to analyze sample video sequences of the students of the pretest and posttest game performance, so they could determine the chronological order of the same. The experts, all with doctoral degrees in Physical Education and more than five years of experience in teaching, research and analysis of the game in basketball and floorball, agreed to participate. Using the procedures outlined by Hastie et al. (2013), two video clips of every team (eight files in total, four of basketball and four of floorball) were analyzed during three game analysis sessions, involving a total of approximately four hours. It should be noted that file names of these video clips were blind-labelled to let a more objective review.

During the sessions, experts were together in a room where video projections were made. At the beginning of the session, they were provided with an analysis form and given a detailed explanation on the tasks to be done. The first task was to make a comment on each of the following aspects of play: (a) attacking play, (b) defensive play, (c) technical quality of the players, and (d) tactical decisions made throughout the games. The second task was to judge whether they appreciate distinctive qualitative differences in the overall quality of each team's performance across their team games, and if so, to note which was superior. Finally, all experts discussed and argued verbally the responses as a group.

Students' and teacher' perception. To evaluate the students and teacher' perception it was created two semi-structured in-depth interviews (post) split into two parts and including closed- and open-ended questions. The first part presented the research context and gather information on the participants. The second part examined the specific evaluation of the Sport Education features (Santiago-Delefosse, et al., 2016).
Both interviews were directed individually by one of the authors and each lasting about thirty minutes. Students' interviews were conducted to all teams (three or four players of team together). The interviews were audio taped, transcribed and later analysed. The main goal was to investigate the perceptions about Sport Education, DM, SE, GP, GI, and the GK improvement.

\section{Data analysis}

Game performance and game knowledge. IBM Statistical Package for Social Sciences (SPSS) version 20.0 was used to analyze DM, SE, GP, GI, and GK. The normal data distribution was checked with the Kolmogorov-Smirnov test. We performed intra- and inter-explorations of data in order to check the possible differences by group, sport, and skill level. We used a $t$ test to: (a) determine possible significant pretest-posttest differences in the means of the analyzed variables in each group (pretest-posttest results), and (b) determine possible significant group differences in the means of the analyzed variables (group-differences results). We determined whether the results were influenced by the effect of the students' random assignment, using the t test on the pretest data. All comparisons were made: (a) general level, and (b) according to the skill level of students. Statistical significance was set at $p \leq 0.05$. Descriptive data provided means and standard deviations for all variables. Cohen's $d$ was used to measure the effect size (0.2 small, 0.4 medium, 0.8 large, Cohen, 1988).

Experts' commentary of game performance. First, the level of agreement between experts with respect to improvement was determined. Second, for those who indicated a perception of improvement, the "percentage correct" was calculated (i.e. those experts placing the videos in the appropriate temporal order, either pretest or postes videos). Third, the descriptive responses concerning game play quality were analysed inductive and deductively according to the study dependant variables.

Interviews. The qualitative data about the teacher and students' perception of the game performance variables were collected from the focus group report and analysed through a combination of inductive and deductive procedures. Directed by Braun and Clarke's (2006) phases of thematic analysis. This included: (a) familiarization with the data (transcribing, reading and 


\section{Unidades Didácticas de Educación Deportiva para la Educación Primaria}

re-reading the data); (b) generating initial indicators (coding interesting features of the data in a systematic fashion across the entire data set); (c) collating indicators into existing categories (game performance, game involvement, skill level and game knowledge); (d) reviewing indicators (checking if the codes work in relation to the allocated category); and (e) defining and naming indicators (refining the specifics of each category and the overall story the analysis tells). In order to examine, clarify and think about data in a more sensitive way, first two authors through a reflective dialogue which included discussed interpretations of the transcripts, then critically examined those that were generated in the first independent analysis (Farias et al., 2018) in a process of working back and forth between data and theory. Through regular peer debriefings held between the teacher, the first author and the co-authors, the research team was involved in a collaborative approach within the interpretational analysis. The goal of these strategies was to ensure interpretative validity while minimizing the risk of individual research bias (Farias et al., 2018).

\section{RESULTS}

\section{Game performance and game knowledge}

There were no statistically significant improvements from pretest to posttest either in general or considering the higher skill level students (Table 1). However, the lower skill level students improved in $\operatorname{DM}(p=.011, d$ $=2.59)$, GP ( $p=.027, d=2.36)$, and GI ( $p=.029, d$ $=.55)$ after the basketball unit and in DM ( $p=.037, d$ $=1.30)$ and GP $(p=.020, d=1.65)$ after the floorball unit (Table 1). In terms of the second purpose of the study, the lower skill level students who experienced the basketball unit showed statistically significant improvements in comparison to the lower skill level students who experienced the floorball unit in DM ( $p$ $=.015, d=1.72)$ and GI $(p=.030, d=1.47)$. In addition, statistically significant differences were ratified by the high $\mathrm{d}$ (from .55 to 2.59 , Table 1 ). The randomization of the students' distribution influenced the results in DM $(t=-2.67, p=.021)$ and GK $(t=$ 2.13, $p=.043)$. The students in the basketball unit reported higher results than those of the floorball unit (Table 1). Despite the fact that there was no statistical effect on the remaining variables $(p>.05)$, the scores were higher in the pretest of the basketball unit (Table $1)$.

\section{Experts' commentary of game performance}

Experts considered that there was not a clear improvement on GP variables, neither in basketball nor in floorball since they were unable to identify in which of the clips the students performed better. Consequently, the panel agreed their final responses establishing the correct order of the clips based on small details of each clip, such as some technical improvements or better organization in space, etc. Figure 2 shows some sample experts' comments on the GP of the students during data collection.

\section{Interviews}

Most students highlighted the Sport Education core features during their interviews. They valued the teamwork for the improvement of their game performance variables and the individual roles for the improvement of their content knowledge (Figure 3). According to the teacher' comments, higher skill level students were worried about the involvement of the whole team to achieve success. Overall, the teacher pointed out that most of the students showed a slower learning in game performance variables in the floorball unit since their initial skill level was very low (see Figure 3). 


\section{Unidades Didácticas de Educación Deportiva para la Educación Primaria}

Table 1. Means $(M)$, standard deviations $(S D)$, and significant differences of the variables at the pretest and posttest in the basketball and floorball units

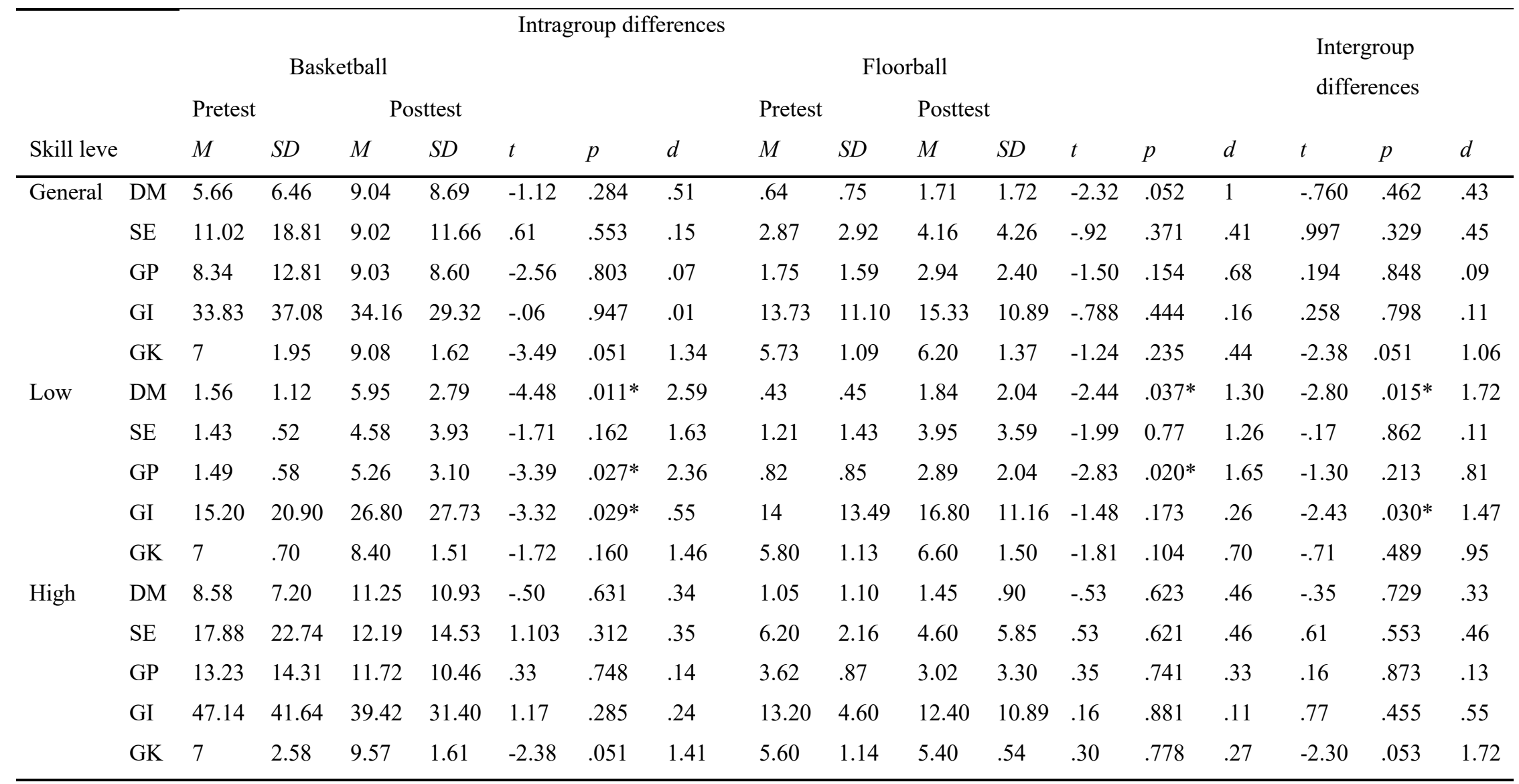

Note. $M$ : mean, $S D$ : standard deviation, $C V$ : coefficient of variation, ${ }^{*} p<.05$. 


\section{Unidades Didácticas de Educación Deportiva para la Educación Primaria}

\begin{tabular}{|c|c|c|c|}
\hline \multicolumn{2}{|l|}{ Pretest comments } & \multicolumn{2}{|l|}{ Posttest comments } \\
\hline Basketball & Floorball & Basketball & Floorball \\
\hline $\begin{array}{l}\text { Decision Making: } \\
\text { E1: "Overall the team game is poor. } \\
\text { They made many passes but with } \\
\text { many failures" } \\
\text { Skill Execution: } \\
\text { E1: "Students throw the ball with } \\
\text { two hands and poor technique" } \\
\text { Game involvement: } \\
\text { E4: "It is hard to see team cohesion. } \\
\text { They just run after the ball" }\end{array}$ & $\begin{array}{l}\text { Decision Making: } \\
\text { E2: "There are no purposes in the } \\
\text { actions performed" } \\
\text { Skill Execution: } \\
\text { E1: "Students hold the stick just } \\
\text { with one hand" } \\
\text { Game involvement: } \\
\text { E4: "Most of them show } \\
\text { distractions during the game" }\end{array}$ & $\begin{array}{l}\text { Decision Making: } \\
\text { E1, E2: "Now, they use the space } \\
\text { better" } \\
\text { Skill Execution: } \\
\text { E4: "There is more variety in the } \\
\text { passes (not just chest-pass) " } \\
\text { Game involvement: } \\
\text { E2, E3: "Greater collaboration; and } \\
\text { involvement of the students in their } \\
\text { teams" } \\
\text { E5: "The student-referees and } \\
\text { student-coaches show a great } \\
\text { commitment" }\end{array}$ & $\begin{array}{l}\text { Decision Making: } \\
\text { E4: "Students have a better position } \\
\text { along the practice-area" } \\
\text { E5: "It is easier to see some } \\
\text { intentionality in the game" } \\
\text { Skill Execution: } \\
\text { E2: "The students keep the ball a } \\
\text { little bit better along the game" } \\
\text { Game involvement: } \\
\text { E4: "The students are organized and } \\
\text { collaborate better between } \\
\text { themselves" }\end{array}$ \\
\hline
\end{tabular}

Figure 2. Sample experts' comments on game performance during data collection. E1 = Expert 1; E2 = Expert 2; E3 = Expert 3; E4 = Expert 4; E5 = Expert 5 


\section{Unidades Didácticas de Educación Deportiva para la Educación Primaria}

\section{DISCUSSION}

The purposes of the paper were: (a) to explore the effect of two-Sport Education invasion games units (basketball and floorball) on game performance and game knowledge of Primary Education students according to their skill level, and (b) to know whether there were differences according to the sport taught (basketball and floorball). The results did not confirm the hypothesis, because the students did not show statistically significant improvements on game performance and GK at the end of both units. However, lower skill level students improved in DM, GP and GI in the basketball unit and in DM and GP in the floorball unit. Indeed, there were differences according to the sport taught, because the lower skill level students improved more in DM and GI after the basketball unit in comparison to their mates after the floorball unit. These differences between units could be due to the higher values reported by the students at the pretest in the basketball unit. Additionally, results were consistent with prior evidence showing that Sport Education is particularly advantageous for students of lower skill level (Hastie, 1998; Mesquita et al., 2012). According to Mesquita et al. (2012) the tasks structures applied, mainly game forms, could be determinant particularly for the lower skill students (Figure 1).

Nonetheless, these findings were different to those reported by Mahedero et al. (2015), Hastie et al. (2009), and Pritchard et al. (2008) where students in Sport Education not only improved in their ability to make appropriate DM but also in SE. Given that game performance is a function of decision making and skill execution, improvement in game play could have been influenced different depending on the domain in the sport taught or the skill level of player. In that sense, experts shown the players had poor tactical and technical sophistication in their game play in the posttest measure at the end of the season (Figure 2). Indeed, the teacher exposed that many students struggled with the technical demands of the individual elements especially in floorball (Figure 3). Consequently, inductive analysis of the experts' comments (Figure 2) and interviews (Figure 3) were unpacked into the two following themes: (a) slower learning in primary students due to the sport taught, and (b) differences in skill level in heterogeneous teams.

\section{Slower learning in primary students due to the sport} taught

As reported by French et al. (1991) and Mesquita et al. (2012) the previous sporting experience of all students, both more and less skilled, was important for learning being an outstanding factor in promoting a positive cycle between skill, attitude and learning. Consequently, the teacher emphasized that students were more familiar with basketball (Figure 3) as opposed of the lack of previous experiences in floorball. Furthermore, the teacher highlighted a slow technical learning along the floorball unit. He pointed out that the initial skill level was extremely low and most of the students were focused on improving the grip and handling of the stick and not in the tactical development (Figure 3). This was something previously reported by McCaughtry et al. (2004) when teaching Sport Education soccer to seventh and eighth graders. In addition, in our study the experts showed a general agreement that the student game performance in basketball was higher than in floorball (Figure 2). According to the experts, there was not enough DM during the game play because of that technical issue. Some of the tactical improvement was in basketball, however game performance scores were not very high. It is possible that the age of the students conditioned our findings, as the students reported in the interviews (Figure 3) and has been previously reported by Sinelnikov and Hastie (2008). In contrast, Fárias et al. (2018) analysed three consecutive Sport Education units and found statistically significant pre-test to post-test improvements both in GP and GI in the second (handball) and third (football), but not in the first (basketball). 


\section{Unidades Didácticas de Educación Deportiva para la Educación Primaria}

\begin{tabular}{|c|c|}
\hline Students' interview & Teacher's interview \\
\hline $\begin{array}{c}\text { Game performance } \\
\text { (Decision Making and Skill Execution) }\end{array}$ & $\begin{array}{c}\text { Game performance } \\
\text { (Decision Making and Skill Execution) }\end{array}$ \\
\hline $\begin{array}{l}\text { - "The teammates tell you what you have to do or where } \\
\text { to go" (B) } \\
\text { - "In floorball we passed the ball more times and we shot } \\
\text { to goal always that we had an opportunity" (F) }\end{array}$ & $\begin{array}{l}\text { - "The students' improvement in game performance } \\
\text { was higher in Sport Education units due to the } \\
\text { modified-game situations" (B, F) } \\
\text { - "The students' technical and tactical achievement } \\
\text { were affected by the sport, being more visible in } \\
\text { basketball" (B, F) } \\
\text { - "In basketball unit, the game performance was } \\
\text { better since the students used to play it in their free } \\
\text { time. In contrast, in floorball they don't, so the } \\
\text { technical improvements were very slow" (B, F) }\end{array}$ \\
\hline Game involvement & Game involvement \\
\hline $\begin{array}{l}\text { - "In floorball we have learned to relate to our } \\
\text { teammates" (F) } \\
\text { - "With floorball we worked in groups" (F) } \\
\text { - "Working in group is awesome, the learning activities } \\
\text { are divided among all" (B, F) }\end{array}$ & $\begin{array}{l}\text { - "I highlighted a greater involvement of the students } \\
\text { from the beginning to the end in the Sport } \\
\text { Education units" (B, F) } \\
\text { - "I perceived less conflicts and discussions between } \\
\text { the students in Sport Education units, thanks to the } \\
\text { fairplay points and team roles, such as referees and } \\
\text { captains, etc." (B, F) }\end{array}$ \\
\hline Skill level & Skill level \\
\hline $\begin{array}{l}\text { - "Working as a team allow us to support and learn } \\
\text { more" (B, F) } \\
\text { - "We shared our knowledge with the lower skill } \\
\text { teammates" (B, F) } \\
\text { - "Overall, we helped each other" (B, F) }\end{array}$ & $\begin{array}{l}\text { - "The higher skill level students in Sport Education } \\
\text { were more worried on the cohesion and } \\
\text { involvement of the whole team to be successful" } \\
(\mathrm{B}, \mathrm{F}) \\
\text { - "The higher and lower skill students became more } \\
\text { involved because they helped each other. They } \\
\text { created a team feeling" }(\mathrm{B}, \mathrm{F})\end{array}$ \\
\hline Game Knowledge & Game Knowledge \\
\hline $\begin{array}{l}\text { - "We learned more practicing the Sport Education } \\
\text { units because we had to assume different roles, such } \\
\text { us, coach or score-keeper" (B, F) } \\
\text { - "If you were the referee you had to know everything } \\
\text { about the rules of the game" }(\mathrm{B}, \mathrm{F})\end{array}$ & $\begin{array}{l}\text { - "Overall, the students learned very few floorball } \\
\text { concepts and rules, because they had the focus on } \\
\text { the technical issues, especially on the handling and } \\
\text { driving the ball" (F) }\end{array}$ \\
\hline
\end{tabular}

Figure 3. Results from students' and teacher' interviews. $\mathrm{B}=$ basketball unit, $\mathrm{F}=$ floorball unit. 


\section{Unidades Didácticas de Educación Deportiva para la Educación Primaria}

\section{Differences in skill level in heterogeneous teams}

According to the experts, there were important differences in skill level within the teams (Figure 2). This could affect the learning experiences of the students in both units, as Silverman (1993) suggested. Despite the fact that the results were affected by the sport, not all students improved on game performance variables and GK in basketball. There were only improvements in DM and GP in lower skill students. For these students as previous research has showed, the existence of the individual roles generated selfconfidence (Kinchin et al., 2004) and allowed them to feel comfortable within the team (Gutiérrez et al., 2014). This positive affiliation feeling could condition the appropriate game performance variables as they reported in the interviews (Figure 3).

Nevertheless, the findings were not consistent with the results found by Pereira et al. (2015) after an experience with athletics. In their experience, the higher skill level students improved in the different tests done at the end of the teaching unit. This could have been due to the different content taught (invasion games vs athletics). The higher skill level students were more likely to help their lower-level teammates than to focus on their individual improvement (Figure 3 ) so they developed an identity and achieved social goals from an ecological perspective, as Hastie (2000) suggested. However, despite the higher skill level students helped their lower-level teammates to achieve success, it was not enough to achieve significant learning in their GP and GK.

The GK results found in this paper were different with those obtained by Hastie et al. (2013) in athletics. The differences could be related to the students age group (secondary vs primary). These results also contrasted with Layne and Yli-piipari (2015) where students improved their GK at the end of a Sport Education unit because of the longer length of class time (Siedentop, 2002). Nevertheless, their sample was of university students. In this paper, despite the students had a perception of improvement in GK, the teacher argued that the over focus on the technical issues could hide their GK. This reinforces the idea that as Mesquita et al. (2012, p. 217) reported 'in order to promote a truly inclusive pedagogy, teachers should take into account the previous sporting experiences of all students, both more and less skilled students, when they plan their learning tasks'.

\section{Limitations and future directions}

These findings should be interpreted with caution due to the quasi-experimental nature of the design and the lack of a control group. In addition, participants were selected on purpose because students and teacher had no prior experience with Sport Education. Furthermore, the number of participants was small. It would have been interesting to analyse the results at the end of the first unit to see whether there were improvements between units. Further research might be done exploring differences by sex, as well as the effect of the teachers' gender on the students' achievements.

\section{CONCLUSION}

In summary, the sport taught, basketball in this case, conditioned the results in the variables related with game performance and GK. The largest improvements were obtained by lower level students that experienced the basketball unit, mainly in DM, GP and GI. The central tenet could be based on the previous experience of the primary students in basketball versus floorball, with the aggravating complexity of learning to handle the stick to play. Given this scenario, it is suggested that enacting Sport Education units of invasion games with implement such as floorball, at the primary level, might require more lessons and longer teaching units in order to guarantee a minimum level of technical and tactical improvement. In addition, the teaching and learning of invasion games with implement (i.e., as floorball, hockey) could require a more explicit instruction. In practical terms, that means to give them information at the beginning of each lesson on the "hows" and "whys" of contentbased instruction, with meaningful examples and deeper explanations. We agree with the idea reported by Harvey et al. (2018), that it is not a sufficient condition for learning to occur, that simply manipulating constraints and letting the 'game be the teacher', especially when teaching invasion games with implement with primary students. Nevertheless, it seems important to consider, not just the structural features of Sport Education and how to enact them, but also the tactical and technical content and how to teach them. To date, previous studies with Sport Education have not provided the substantive details of pedagogies that addressed the progressive development of learning tasks or experiences that were incorporated during the learning unit. 


\section{Unidades Didácticas de Educación Deportiva para la Educación Primaria}

Additionally, it should be analysed the impact of Sport Education on the game performance variables and GK of other different invasion games with implement as well as to deepen in the appropriate choice of these contents according to the student's age and the skill level.

\section{REFERENCES}

1. Araújo, R., Hastie, P. A., Pereira, C., Mesquita, I. (2017). The evolution of student-coach's pedagogical content knowledge in a combined use of sport education and the step-game-approach model. Physical Education and Sport Pedagogy, 22 , 518-535. https://doi.org/10.1080/17408989.2017.1294668

2. Araújo, R., Mesquita, I., Hastie, P. A. (2014). Review of the status of learning in research on sport education: Future research and practice. Journal of Sports Science and Medicine, 13, 846858.

3. Araújo, R., Mesquita, I., Hastie, P. A., Pereira, C. (2016). Students' game performance improvements during a hybrid sport educationstep-game-approach volleyball unit. European Physical Education Review, 22, 185-200. https://doi.org/10.1177/1356336x15597927

4. Barker, D., Quennerstedt, M. (2017). Power and group work in physical education: A Foucauldian perspective. European Physical Education Review, 23, 339-353. https://doi.org/10.1177/1356336x15620716

5. Braun, V., Clarke, V. (2006). Using thematic analysis in psychology. Qualitative Research in Psychology, 3(2), 77-101. https://doi.org/10.1191/1478088706qp063oa

6. Brock, S. J., Hastie, P. A. (2017). Students' verbal exchanges and dynamics during sport education. European Physical Education Review, 23, 354365. https://doi.org/10.1177/1356336x16629582

7. Browne, T. B., Carlson, T. B., Hastie, P. A. (2004). A comparison of rugby seasons presented in traditional and sport education formats. European Physical Education Review, 10, 199214. https://doi.org/10.1177/1356336x04044071
8. Cohen, J. (1988). Statistical power analysis for the behavioral sciences (2nd ed.). Lawrence Earlbaum Associates.

9. Dyson, B., Griffin, L., Hastie, P. A. (2004). Theoretical and pedagogical considerations for implementing sport education, tactical games, and cooperative learning instructional models. Quest, 56 , 225-239. https://doi.org/10.1080/00336297.2004.1049182 3

10. Farias, C., Hastie, P. A., Mesquita, I. (2018). Scaffolding student-coaches' instructional leadership toward student-centred peer interactions: A yearlong action-research intervention in sport education. European Physical Education Review, 24, 269-291. https://doi.org/10.1177/1356336X16687303

11. Farias, C., Mesquita, I., Hastie, P. A. (2019). Student game-play performance in invasion games following three consecutive hybrid Sport Education seasons. European Physical Education Review, 25(3), 691-712. https://doi.org/10.1177/1356336X18769220

12. Farias, C., Valério, C., Mesquita, I. (2018). Sport education as a curriculum approach to student learning of invasion games: Effects on game performance and game involvement. Journal of Sports Science and Medicine, 17, 56-65.

13. French, D., Rink, J., Rikard, L., Mays, A., Lynn, S., Werner, P. (1991). The effects of practice progressions on learning two volleyball skills. Journal of Teaching in Physical Education, 10, 261-274.

14. French, K. E., Thomas, J. (1987). The relation of knowledge development to children's basketball performance. Journal of Sport Psychology, 9, 1532. https://doi.org/10.1123/jsp.9.1.15

15. Gutiérrez, D., García, L. M., Chaparro, R., Fernández, A. J. (2014). Sport education model in second grade. Teachers and students' perceptions. Cuadernos de Psicología del Deporte, 2, 131-144.

16. Harvey, S., Pill, S., Almond, L. (2018). Old wine in new bottles: A response to claims that teaching games for understanding was not developed as a theoretically based pedagogical framework. Physical Education and Sport Pedagogy, 23, 166- 


\section{Mahedero et al.}

180.

https://doi.org/10.1080/17408989.2017.1359526.

17. Hastie, P. A. (1998). Skill and tactical development during a sport education season. Research Quarterly for Exercise and Sport, 69, 368-379.

https://doi.org/10.1080/02701367.1998.1060771 1

18. Hastie, P. A. (2000). An ecological analysis of a sport education season. Journal of Teaching in Physical Education, 19, 355-373.

19. Hastie, P. A., Calderón, A., Rolim, R. J., Guarino, A. J. (2013). The development of skill and knowledge during a sport education season of track and field athletics. Research Quarterly for Exercise and Sport, 84, 336-344. https://doi.org/10.1080/02701367.2013.812001

20. Hastie, P. A., Casey, A. (2014). Fidelity in models-based practice research in sport pedagogy: A guide for future investigations. Journal of Teaching in Physical Education, 33, 422-431.

21. Hastie, P. A., Layne, T. E., Mesquita, I. (2013). Evaluating game performance from external experts in sport education. Revista Portuguesa de Ciências do Desporto, 13, 23-37.

22. Hastie, P. A., Sinelnikov, O. A. (2006). Russian students' participation in and perceptions of a season of sport education. European Physical Education Review, 12, 131-151. https://doi.org/10.1177/1356336x06065166

23. Hastie, P. A., Sinelnikov, O. A., Guarino, A. J. (2009). The development of skill and tactical competencies during a season of badminton. European Journal of Sport Science, 9, 133-140. https://doi.org/10.1080/17461390802542564

24. Hastie, P. A. Wallhead, T. (2016). Models-based practice in physical education: The case for sport education. Journal of Teaching in Physical Education, 35, 390-399.

25. Hastie, P. A., Ward, J. K., Brock, S. J. (2017). Effect of graded competition on student opportunities for participation and success rates during a season of sport education. Physical Education and Sport Pedagogy, 22, 316-327. https://doi.org/10.1080/17408989.2016.1203888
26. Hordvik, M., MacPhail, A., Ronglan, L. T. (2017). Teaching and learning sport education: A selfstudy exploring the experiences of a teacher educator and pre-service teachers. Journal of Teaching in Physical Education, 36, 232-243.

27. Hordvik, M., MacPhail, A., Ronglan, L. T. (2019). Learning to teach sport education: Investigating a pre-service teacher's knowledge development. Sport, Education and Society, 24, 51-65. https://doi.org/10.1080/13573322.2017.1322948

28. Kirk, D. (2013). Educational value and modelsbased practice in physical education. Educational Philosophy and Theory, 45(9), 973-986. https://doi.org/10.1080/00131857.2013.785352

29. Iserbyt, R., Ward, P., Martens, J. (2016). The influence of content knowledge on teaching and learning in traditional and sport education contexts: An exploratory study. Physical Education and Sport Pedagogy, 21, 539-556. https://doi.org/10.1080/17408989.2015.1050662

30. Kinchin, G. D., Wardle, C., Roderick, S., Sprosen, A. (2004). A survey of year 9 boys' perceptions of sport education in one English secondary school. Bulletin of Physical Education, 40(1), 27-40.

31. Lafont, L., Rivière, C., Darnis, F., Legrain, P. (2017). How to structure group work? Conditions of efficacy and methodological considerations in physical education. European Physical Education Review, 23, 327-338. https://doi.org/10.1177/1356336x15626639

32. Layne, T., Yli-Piipari, S. (2015). Effects of the sport education model on university students' game performance and content knowledge in basketball. Journal of Sports Research, 2(2), 2436.

https://doi.org/10.18488/journal.90/2015.2.2/90.2 .24 .36

33. Lee, A. M., Keh, N. C., Macill, R. A. (1993). Instructional effects of teacher feedback in physical education. Journal of Teaching in Physical Education, 12, 228-243.

34. Mahedero, M. P., Calderón, A., Arias-Estero, J. L., Hastie, P. A., Guarino, A. J. (2015). Effects of student skill level on knowledge, decision making, skill execution and game performance in a minivolleyball sport education season. Journal of Teaching in Physical Education, 34, 626 -641. 


\section{Unidades Didácticas de Educación Deportiva para la Educación Primaria}

35. Mahedero, M. P., Calderón, A., Hastie, P., AriasEstero, J. L. (2021). Grouping students by skill level in mini-volleyball: Effect on game performance and knowledge in sport education. Perceptual and Motor Skills, 128(4), 1851-1871. https://doi.org/10.1177/00315125211021812

36. McCaughtry, N., Sofo, S., Rovegno, I., CurtnerSmith, M. (2004). Learning to teach sport education: Misunderstandings, pedagogical difficulties and resistance. European Physical Education Review, 10, 135-155. https://doi.org/10.1177/1356336x04044068

37. Mesquita, I., Farias, C., Hastie, P. (2012). The impact of a hybrid sport education-invasion games competence model soccer unit on students' decision making, skill execution and overall game performance. European Physical Education Review, $\quad 18, \quad 205-219$. https://doi.org/10.1177/1356336X12440027

38. Oslin, J. L., Mitchell, S. A., Griffin, L. L. (1998). The game performance assessment instrument (GPAI): Development and preliminary validation. Journal of Teaching in Physical Education, 17, 231-243.

39. Pereira, J., Hastie, P. A., Araújo, R., Farias, C., Rolim, R., Mesquita, I. (2015). A comparative study of students' track and field technical performance in sport education and in a direct instruction approach. Journal of Sports Science and Medicine, 14, 118-127.

40. Perlman, D. J. (2010). Change in affect and needs satisfaction for amotivated students within the sport education model. Journal of Teaching in Physical Education, 29, 433-445.

41. Pope, C. C., Grant, B. C. (1996). Student experiences in sport education. Waikato Journal of Education, 2, 103-118. https://doi.org/10.15663/wje.v2i1.512

42. Pritchard, T., Hawkins, A., Wiegand, R., Metzler, J. N. (2008). Effects of two instructional approaches on skill development, knowledge, and game performance. Measurement in Physical Education and Exercise Science, 12, 219-236. https://doi.org/10.1080/10913670802349774

43. Santiago-Delefosse, M., Gavin, A., Bruchez, C., Roux, P., Stephen, S. L. (2016). Quality of qualitative research in the health sciences: Analysis of the common criteria present in 58 assessment guidelines by expert users. Social Science \& Medicine, 148, 142-151. https://doi.org/10.1080/10913670802349774

44. Siedentop, D. (2002). Sport education: A retrospective. Journal of Teaching in Physical Education, 21, 409-418.

45. Siedentop, D., Hastie, P. A., Van der Mars, H. (2019). Complete guide to sport education (3er ed). Human Kinetics.

46. Silverman, S. (1993). Student characteristics, practice, and achievement in physical education. The Journal of Educational Research, 87, 54-61.

47. Silverman, S., Woods, A. M., Subramaniam, P. R. (1998). Task structures, individual student feedback, and student skill level in physical education. Research Quarterly for Exercise and Sport, 69, 420-424. https://doi.org/10.1080/02701367.1998.1060771 8

48. Sinelnikov, O. A. (2009). Sport education for teachers: Professional development when introducing a novel curriculum model. European Physical Education Review, 15, 91-114. https://doi.org/10.1177/1356336X09105213

49. Sinelnikov, O. A., Hastie, P. A. (2008). Teaching sport education to Russian students: An ecological analysis. European Physical Education Review, 14 , 203-222. https://doi.org/10.1177/1356336x09105213 